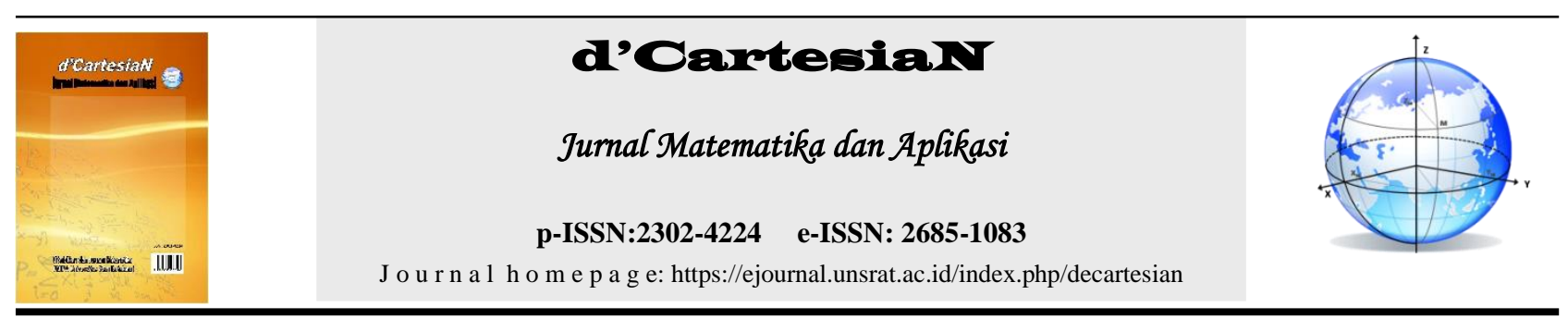

\title{
THE EFFECT OF ECONOMIC GROWTH, UNEMPLOYMENT RATE AND HUMAN DEVELOPMENT ON POVERTY IN INDONESIA (Panel Model Approach in 4 Poorest Provinces)
}

\author{
Ananto Wibowo ${ }^{*}$, M. Rismawan Ridha ${ }^{2}$ \\ ${ }^{1}$ Badan Pusat Statistik Kabupaten Ciamis, Jawa Barat, Indonesia \\ ${ }^{2}$ Badan Pusat Statistik Kabupaten Maluku Tengah, Maluku, Indonesia \\ *Corressponding author: ananto.wibowo@bps.go.id
}

\section{A B S T R A C T}

The implementation of various policies in poverty alleviation in Indonesia has yielded good results. This condition is reflected by the downward trend in the percentage of poor people who reached a single digit in 2018. However, this has not much changed the conditions in some of the poorest provinces such as Maluku, East Nusa Tenggara, West Papua, and Papua. This study aims to analyze the effect of Economic Growth, Unemployment Rate, and Human Development Index (HDI) on poverty in the four poorest provinces from 2011 to 2018. The research data source from Statistics Indonesia (BPS) with the analytical tool used in estimating the panel data regression model is the Fixed Effect Model (FEM). The regression results show that the adjusted R-Square of 97.79 percent and have met all diagnostic assumptions tests. Based on empirical studies, it is found that economic growth and HDI have a negative effect on poverty. In reverse, the Unemployment Rate has an insignificant effect.

\section{ARTICLE INFO}

Accepted : 21 January 2021

Accepted after revision : 14 April

2021

Available online : 15 April 2021

Keywords:

Poverty

Economic Growth

HDI

Unemployment Rate

Panel Regression

\begin{abstract}
A B S T R A K
Penerapan berbagai kebijakan dalam pengentasan kemiskinan di Indonesia telah membuahkan hasil yang baik. Hal ini tercermin dari tren penurunan persentase penduduk miskin yang mencapai satu digit pada tahun 2018. Namun, hal ini tidak banyak mengubah kondisi di beberap $\neg$ a provinsi termiskin seperti Maluku, Nusa Tenggara Timur, Papua Barat dan Papua. Penelitian ini bertujuan untuk menganalisis pengaruh Pertumbuhan Ekonomi, Tingkat Pengangguran Terbuka, dan Indeks Pembangunan Manusia (IPM) terhadap kemiskinan di 4 Provinsi tersebut dari tahun 2011 hingga 2018. Sumber data penelitian berasal dari Badan Pusat Statistik (BPS) dengan alat analisis yang digunakan dalam mengestimasi model regresi data panel yaitu Fixed Effect Model (FEM). Hasil pemodelan memiliki adjusted R-Square sebesar 97,79 persen dan telah memenuhi seluruh uji asumsi diagnostik. Berdasarkan kajian empiris diperoleh bahwa Pertumbuhan Ekonomi dan IPM berpengaruh negatif signifikan terhadap tingkat kemiskinan. Sebaliknya, Tingkat Pengangguran tidak berpengaruh signifikan.
\end{abstract}

\author{
Kata Kunci: \\ Kemiskinan \\ Pertumbuhan Ekonomi \\ IPM \\ Tingkat Pengangguran \\ Regresi Panel
}

\section{INTRODUCTION}

One of the main focuses in the Agenda of Sustainable Development Goals (SDGs) is eradicating extreme poverty, which is the greatest global challenge and an indispensable requirement toward sustainable development. Poverty is mainly seen as a complex problem because it is always related to many social issues like welfare, unemployment, education, and health problems. However, governments around the world use poverty as a prime benchmark for the success of the development, including in Indonesia. Since March 2018, Indonesia has reached a new milestone in poverty alleviation. Based on the data from Statistics
Indonesia, the poverty rate in Indonesia has decreased to 9,82 percent. This record means the number of poor people recorded at 25,95 million. It is the lowest level ever recorded. This achievement is getting better, with the recorded poverty rate decreased to 9,22 percent in September 2019. Despite the trend of improvement in poverty alleviation, from 2015 to 2019, several provinces have consistently had the highest percentage of poor people in Indonesia, including Maluku, East Nusa Tenggara, West Papua, and Papua. It is in contrast to knowing the fact that these four provinces are endowed with abundant natural resources, ranging from mining resources to large marine products, which 
are the source of engines in advancing the economy and alleviating poverty.

Statistics Indonesia recorded the percentage of poor people in Papua province in September 2019 was 26,55 percent, which decreased to 1,44 percentage points from 2015. Yet, Papua is still the first rank of the poorest provinces. Its neighboring province, West Papua, has seen significant improvements in poverty alleviation. The percentage of poor people in West Papua has decreased by 4,31 percentage points from 2015 to 21.37 percent in 2019. Unfortunately, this incredible performance has not been able to displace West Papua as the second poorest province in Indonesia. Nusa Tenggara Timur and Maluku also face the same poverty condition since back then. The phenomenon requires revision on many strategic government policies so that poverty alleviation can have a sovereign impact, both through theoretical or public policy studies.

There are several theoretical studies conducted to find out the relationship between Economic growth, unemployment, and Human Development on poverty. A study by Ridho [1], Sembiring [2], and Susanti [3] pointed out that Economic Growth and unemployment has a positive and significant impact on poverty. A high level of economic growth in a developing region sometimes creates economic inequality, which means unequal access to wealth and income. An only a small portion of the community holds a majority percentage of the economic activities. The Unemployment rate contributes to the poverty rate because the few people do not have the adequate opportunity to meet their basic needs. Both of these will directly increase the poverty rate. On the other hand, HDI has a negative and significant effect on the poverty rate.

Based on the description above, this study aims to analyze the effect of Economic Growth, Unemployment Rate, and HDI on poverty rate with a case study of the four poorest provinces in Indonesia through a statistical panel data regression model. By using panel data, Researchers can investigate various economic processes at the same time calculating heterogeneity between the region and the dynamic effects that cannot be seen in cross-section data [4].

\section{RESEARCH METHOD \\ Data}

The empirical dataset used in this research is panel data which is a combination of cross-section and time-series data in 4 provinces in Indonesia. All data were obtained from Statistics Indonesia from the period of 2011-2018. The dependent variable used is the poverty rate, while the Independent variables are Economic Growth, Unemployment rate, and the Human Development Index (HDI). The construction of the Panel regression Model and all its classical assumptions are done through the use of Eviews 9.o while Geographic Information System is used to create a thematic map.

\section{Panel Data Regression Analysis Procedures}

The panel regression is divided into three techniques as an implication of the assumptions underlying, namely Common Effect Model (CEM), Fixed Effect Model (FEM), and Random Effect Model (REM) [4]. The common approach in the panel regression is CEM, supposed as follows [2]:

$$
y_{i t}=\alpha+\beta_{1} X_{1 i t}+\beta_{2} X_{2 i t}+\cdots+\beta_{k} X_{k i t}+\varepsilon_{i t}
$$

Where $i=1,2,3, \ldots, n$ and $t=1,2,3, \ldots T$.

$\alpha$ is an intercept and $\beta$ is a slope, while $y$ and $X$ each are dependent and independent variables. This model assumes constant intercept and slope coefficient for all cross-section units and time [5].

Unlike CEM, FEM accommodates the difference between individuals through its intercept so that the intercept changes between individuals. The equation of the FEM model is as follows [6]:

$$
y_{i t}=\alpha+\gamma_{i}+\beta_{1} X_{1 i t}+\beta_{2} X_{2 i t}+\cdots+\beta_{k} X_{k i t}+\varepsilon_{i t}
$$

where $\gamma_{i}$ is the individual effect, where it is assumed to be a fixed parameter. The last model is REM which considers individual effects as part of the error component. The REM equation is written as follows:

$$
y_{i t}=\alpha+\beta_{1} X_{1 i t}+\beta_{2} X_{2 i t}+\cdots+\beta_{k} X_{k i t}+w_{i t}
$$

where $w_{i t}=\varepsilon_{i}+\mu_{i t}$.

Thus, several statistical tests are carried out to determine which model is the best model between CEM, FEM, and REM. The first test is the Chow test:

$$
F=\frac{\left(R S S_{1}-R S S_{2}\right) / n-1}{R S S_{2} /(n T-n-k)} \sim F_{(\alpha ; n-1 ; n T-n-k)}
$$

Where $R S S_{1}$ represents the residual sum of squares of CEM and $R S S_{2}$ represents the residual sum of squares of FEM. If $F>F_{(\alpha ; n-1 ; n T-n-k)}$ then $H_{0}$ is rejected, or at least there is $\gamma_{i} \neq 0$, so it can be concluded that the panel regression model chosen is FEM. The comparison between FEM and REM is carried out through the Hausman test which follows the chi-square distribution. The equation is written as follows [4]:

$$
\begin{gathered}
W=\left(\widehat{\boldsymbol{\beta}}_{F E M}-\widehat{\boldsymbol{\beta}}_{R E M}\right)^{\prime}\left[\operatorname{var}\left(\widehat{\boldsymbol{\beta}}_{F E M}-\widehat{\boldsymbol{\beta}}_{R E M}\right)\right]^{-1}\left(\widehat{\boldsymbol{\beta}}_{F E M}\right. \\
\left.-\widehat{\boldsymbol{\beta}}_{R E M}\right) \sim \chi^{2}{ }_{(k)}
\end{gathered}
$$

where $\widehat{\boldsymbol{\beta}}$ is an estimation vector. If $W>\chi^{2}{ }_{\alpha, k}$ then the best model to use is FEM. In reverse, if $W \leq \chi^{2}{ }_{\alpha, k}$ then the best model to use is REM.

Thus, If FEM is selected, an examination of the residual variance-covariance matrix structure is carried out using the LM test with the formula:

$$
\lambda_{L M}=\frac{T}{2} \sum_{i=1}^{n}\left[\frac{\hat{\sigma}_{i}{ }^{2}}{\hat{\sigma}^{2}}-1\right]^{2} \sim \chi_{(\alpha ; n-1)}^{2}
$$

where $\hat{\sigma}_{i}{ }^{2}$ is an estimation of the residual variance of $-i$ th individual, and $\hat{\sigma}^{2}$ is an estimation of residuals sum of squared of FEM. If $\lambda_{L M}>\chi_{(\alpha ; n-1)}^{2}$ then $H_{0}$ is rejected or variance-covariance of residual are heteroscedastic. We then begin a further $\lambda L M$ test. The equation test is as follows: 


$$
\lambda_{L M}=T \sum_{i=2}^{n} \sum_{j=1}^{i-1} r_{i j}{ }^{2} \sim \chi^{2}\left(\alpha ; \frac{n(n-1)}{2}\right)
$$

If $\lambda_{L M}>\chi^{2}{ }_{\left(\alpha ; \frac{n(n-1)}{2}\right)}$ then $H_{0}$ is rejected where the variance-covariance of residual are heteroscedastic and there is a cross-sectional correlation (Seemingly Uncorrelated Regression/SUR). However, if the decision is failed to reject $H_{0}$ then the best model to use is Generalized Least Squares. The detailed steps to use the panel data regression model are represented in Appendix 1 by Ayunitasanti [7].

\section{RESULT AND DISCUSSION Overview of Research Locus}

This study attempt to present a descriptive analysis of poverty using spatial analysis. Figure 2 (in Appendix) shows the darker the color of an area, the higher the poverty rate. In the research locus, the poverty rate shows a slight decrease from the period of 2011-2018. However, Figure 2 proves that the red color, with the criteria of severe poverty, is still very dominant. This note means that the government should pay more attention to welfare in almost all municipalities and cities in these four provinces.

Spatially, Papua province has the worst average poverty rate than the other three regions (even compared to all regions throughout Indonesia), which was 27.74 percent in 2018. Deiyai and Intan Jaya, which are 43,49 and 42,71 percent, contributed to the worst severe poverty rate.

The lack of infrastructures like health, education, and welfare facilities still overshadows the four provinces in almost all municipalities/cities. This linkage is very reasonable because both are including all red and other colors spectrum indicates a strong correlation between low levels of HDI and high levels of the poverty rate. There are also cases in several regions, where high economic growth correlates with high levels of poverty. For instance, Nduga municipality in 2018 had the lowest HDI value of $\mathbf{2 9 . 4 2}$ (which is the lowest in Indonesia) and a high percentage of poverty, which was 38.13 percent, even though the economic growth of Nduga district is quite high, recorded at 5.74 percent. Meanwhile, Ambon city should be a learning benchmark for other regions. As its poverty rate record at a low level (4.72 percent), the HDI level of Ambon City reached 80.24. Besides, Ambon is also able to achieve a high economic growth level of 6.21 percent.

\section{Panel Model Selection}

In this study, panel regression was applied to the determinant model of the poverty rate. Table 1 . Shows the result of panel data processing with the Chow test. Based on the Chow test at a 5 percent level, the calculated statistics is 9,74 with a probability of 0,0002 . With the critical value used is $\boldsymbol{F}_{(\mathbf{0 . 0 5} ; \mathbf{3} ; 25)}(2,99)$, then the decision is to reject $\boldsymbol{H}_{\mathbf{0}}$ or FEM is better than CEM (intercept in each individual are not equal).
Table 1. The result of the Chow test

\begin{tabular}{|c|c|c|c|}
\hline Test & Statistics & $\begin{array}{c}\text { Degree of } \\
\text { Freedom }\end{array}$ & P-value \\
\hline $\begin{array}{c}\text { Cross- } \\
\text { Section } F\end{array}$ & 9,74 & $3 / 25$ & 0.0002 \\
\hline
\end{tabular}

Thus, we perform the Hausman test to choose between the FEM and REM models. The statistical value of the Hausman test is 29,24 with the probability of 0,0000 . If compared to the critical value of $\chi^{2}{ }_{(3)}$ $(7,81)$, we can conclude that $H_{0}$ is rejected. The conclusion that can be obtained from this Hausman test is that with a confidence level of 95 percent, the best panel data regression estimation model for modeling poverty levels in four provinces is FEM. After the fixed effects model is obtained as the best estimation model, the model has to be checked whether it has homoscedastic properties in the residual variancecovariance structure using the Lagrange Multiplier test (LM test). The results of the LM test statistics are 12,32 with a comparison of critical value $\chi^{2}{ }_{(3)}(7,81)$. Based on the test, we can conclude that the residual variancecovariance structure of FEM is heteroscedastic.

Because the previous LM test showed that the variance-covariance structure of the FEM residuals was heteroscedastic, it was followed by the next test to check whether there was a correlation between individual residuals (provinces) using the $\lambda \mathrm{LM}$ test. The test results show that the test statistic is significant at the 5 percent test level of 12.61 with a critical value $\chi^{2}{ }_{(0.05 ; 6)}$ of 12,59 , the decision is to reject $H_{0}$. Through the test results, with a confidence level of 95 percent, it can be concluded that the FEM residual variance-covariance structure is heteroscedastic, and there is a correlation between provincial residuals and the parameter estimation used is Seemingly Uncorrelated Regression (SUR).

\section{Testing of Assumptions}

As a result of using the panel data regression estimation of FEM, with the parameter estimation used is the SUR model, this method accommodates heteroscedastic and autocorrelation components [8]. Thus, testing of classical assumptions of homoscedastic and non-autocorrelation assumptions is not necessary, so the classical assumption to be applied in this study is only non-multicollinearity between independent variables and the normality of residuals of each province.The value of the Variance Inflation Factor (VIF) for all independent variables shows a result of more than 10, and it can be concluded that the independent variables used do not violate the multicollinearity assumption [9]. The test results are shown in Table 2.

Table 2. The result of the Non-Multicollinearity test

\begin{tabular}{|c|c|}
\hline Variable & VIF \\
\hline $\begin{array}{c}\text { Economic } \\
\text { Growth }\end{array}$ & 1,17 \\
\hline UnEmployment & 1,82 \\
\hline HDI & 2,01 \\
\hline
\end{tabular}


Meanwhile, to check whether the FEM model meets the normality assumption of each province residual, we use the Jarque-Bera test statistic. Table 3 shows that the Jarque-Bera test statistical value of all residuals in the four provinces is less than $\mathrm{X}_{3}: 7.81$. Thus, we can conclude that with a confidence level of 95 percent, the residuals have been normally distributed.

Table 3. The result of Normality test

\begin{tabular}{|c|c|}
\hline Province & JB-Test \\
\hline Nusa Tenggara Timur & 1,32 \\
\hline Maluku & 1,43 \\
\hline Papua Barat & 1,08 \\
\hline Papua & 0,50 \\
\hline
\end{tabular}

\section{Empirical Results}

After testing the classical assumptions of the selected model, the next step is to interpret the model. The estimation equation using FEM with the parameter of SUR model is as follows (Table 4):

$$
\begin{gathered}
P_{i t}=75,46+\gamma_{i}- \\
+0,11 \mathrm{EG}_{i t}-0,79 H D I_{i t}-0,18 U E P_{i t} \\
+\mu_{i t}
\end{gathered}
$$

where:

$P_{i t}=$ Poverty rate of $-i t h$ province in $-t$ time

$H D I_{i t}=$ HDI of $-i t h$ province in $-t$ time

$E G_{i t}=$ Economic growth of $-i t h$ province in $-t$ time

$U E p_{i t}=$ Unemployment rate of $-i t h$ province in $-t$ time

Table 4. Fixed Effect Model with estimation parameter of SUR

\begin{tabular}{|l|c|c|c|}
\hline \multicolumn{1}{|c|}{ Variable } & Coefficient & $\begin{array}{c}\text { Standard } \\
\text { Error }\end{array}$ & P-value \\
\hline C & 75,46 & 4,99 & 0,0000 \\
\hline HDI & $-0,79$ & 0,08 & 0,0000 \\
\hline $\begin{array}{l}\text { Economic } \\
\text { Growth }\end{array}$ & $-0,11$ & 0,05 & 0,0326 \\
\hline Unemployment & $-0,18$ & 0,09 & 0,0523 \\
\hline Fixed Effect & \multicolumn{3}{|l}{$-0,3,23$} \\
\hline NTT-C & 0,01 \\
\hline Maluku-C & \multicolumn{3}{|l}{$-2,11$} \\
\hline Papua Barat-C & \multicolumn{3}{|l}{-01} \\
\hline Papua-C & \multicolumn{3}{|l}{} \\
\hline
\end{tabular}

Table 4. Fixed Effect Model with estimation parameter of SUR (-continued)

\begin{tabular}{|l|l|}
\hline \multicolumn{2}{|l|}{ Weighted Statistics } \\
\hline R-Squared & 0,9822 \\
\hline Adj.R-Squared & 0,9779 \\
\hline F-Statistics & 230,43 \\
\hline
\end{tabular}

Based on the results, the $\mathrm{F}$ stat value is 230,43 with a probability of less than 5 percent, so it can be concluded that the model is valid. Thus, the independent variables (Economic Growth, HDI, and Unemployment) significantly affect the poverty rate in the four poorest provinces.

The coefficient of adjusted R-square reaches 98,22 percent. This value is smaller than the coefficient of determination from $\mathrm{R}$-square because the $\mathrm{R}$ square adjusted has eliminated the effect of adding the independent variables in the model. This adjusted Rsquare means that the FEM model can explain variation of the poverty rate of 98,22 percent, and the remaining 2,21 percent explained by the other factors outside the model.

Looking at the explanatory variables, a partial ttest shows which variables individually affect the poverty rate. If compared to the results of the p-value from all independent variables (at $\alpha=0.05$ ), it is broadly said that all variables are significant to the dependent variable. Also, the intercept is differing for each variable. This indicates that basically, the four provinces in the study period had different levels of poverty.

Mathematically interpret, the economic growth variable will have a negative and significant impact on the poverty level in the four provinces. Based on the empirical result, a one percent increase in economic growth is more likely to decrease the poverty rate by 0,11 percent with the assumption of cateris paribus. These findings support the theory that economic growth has the opposite relationship [10]. This is also supported by the model proposed by Ravallion \& Datt [11]:

$$
d P=\alpha+\beta y+\varepsilon
$$

Where $P$ is the poverty rate, $d P$ is the change of the poverty rate, and $y$ represents economic growth. Meanwhile, $\beta$ is expressed as a model parameter due to a one percent increase in economic growth and is expected to be statistically significant negative. A similar study was conducted by Sumarto and Suryahadi [12], where it completely in line with the negative result $\beta$ obtained. Besides, Research from Dada \& Fanowopo [13] and Dubey \& Tiwari [14] in Nigeria and India, has shown similar conclusions. The effect of the growth in government spending and high household consumption causes a reduction in the level of poverty in the long run. Meanwhile, in other developing countries such as India, the results of the research show that economic growth reduces poverty even though the effect is not geographically uniform. Thus, it can be concluded that economic growth is often regarded as a powerful instrument to reduce the poverty rate and also increasing community welfare in many developing countries (OECD Grup).

On the other hand, a one point increase in HDI level will decrease the poverty rate by 0,79 percent. Based on the publication of Statistics Indonesia, the HDI level continues to grow alongside the reduction in the poverty rate in various regions, including in these four poorest provinces. This condition is also supported by Kanbur and Squire [15], who explains that HDI 
components such as the level of education and the level of health, which intends to improve better, have implications for reducing the poverty rate. Health improvements made by the government are able to improve public health and student attendance at school so that subjects in school can be well accepted. The level of education also makes workers have the skills and knowledge to continue to develop greater company productivity and income. Apart from that, education is also a determining factor in the quality of resources. Through education, a person can think, have the knowledge, and build self-confidence (Statistics Indonesia).

Also, unemployment has a negative effect with the coeffiecient of 0,18 . This value indicates that a one percent increase in unemployment will likely to decrease the poverty rate by 0,18 percent. This result is quite in contrast with the unemployment theory which is linear and in line with the poverty rate. However, statistically, the unemployment did not significantly affect poverty at the research locus.

\section{CONCLUSION}

Based on the results of the analysis and discussion explained, several things can be concluded, the panel data regression modeling with fixed effects and the estimation of the Seemingly Uncorrelated Regression (SUR) parameter is appropriate to analyze the effect of Economic Growth, HDI, and the Unemployment rate on poverty levels in four provinces. The results of the Adjusted R-Square of 0.9822 indicate that the variations in the variables of Economic Growth, HDI, and the unemployment rate are able to explain the variation in the poverty rate by 98.22 percent. All independent variables have a negative effect on the poverty rate in the four poorest provinces in Indonesia, an only Unemployment rate that does not have a significant effect.

\section{REFERENCES}

[1] Ridho, A., Herniwati, R.A. \& Nenik, W. 2018. Analisis Pengaruh PDRB, Tingkat Pengangguran, dan IPM Terhadap Tingkat Kemiskinan di Provinsi Jawa Tengah. Media Ekonomi dan Manajemen UNTAG Semarang.

[2] Sembiring, P., Permata, S.S., Vini, S., \& Jessica, P. 2021. Analisis Pengaruh IPM dan PDRB Terhadap Jumlah Penduduk Miskin di Provinsi Sumatera Utara Tahun 2002-2017. Jurnal Ekonomi dan Ekonomi Syariah. STIE-Al Washliyah. Sibolga.

[3] Susanti, S. 2013. Pengaruh Produk Domestic Regional Bruto, Pengangguran dan Indeks Pembangunan Manusia terhadap Kemiskinan di Jawa Barat dengan menggunakan Analisis Data Panel. Jurnal Matematika Integratif. Unpad. Bandung.

[4] Greene, William H. 2002. Econometric Analysis. New York: Prentice Hall.

[5] Stefan, Camelia. 2016. Human Capital As A Determinant Of The Economic Growth - A Panel Data Approach. United Kingdom: International Journal Of Economics, Commerce And Management.
[6] Baltagi, Badi H. 2011. Econometrics. New York: Springer.

[7] Ayunitasanti, Rani Dwi. 2014. Pengangguran Terdidik di Indonesia Tahun 2002-2012: Tren Profil dan Faktor-Faktor yang Memengaruhinya. Jakarta: Sekolah Tinggi Ilmu Statistik.

[8] Verbeek, Marno. 2004. A Guide to Modern Econometrics: Second Edition. West Sussex: John Wiley \& Sons, Ltd.

[9] Neter, John, William Wasserman, dan Michael H. Kutner. 1989. Applied Linear Regression Models: Second Edition. Boston: Richard D. Irwin, Inc.

[10] Mankiw, N. Gregory. (2005). Macroeconomics: Seventh Edition. New York: Worth Publishers.

[11] Ravallion, Martin, and Gaurav Datt. 1996. "How Important to India's Poor is the Sectoral Composition of Economic Growth?” World Bank Economic Review 10 (1): 1-26.

[12] Sumarto, Sudarno and Asep Suryahadi (2007) 'Indonesia'. In Beyond Food Production: The Role of Agriculture in Poverty Reduction. Fabrizio Bresciani and Alberto Valdés (eds.), Food and Agriculture Organization of the United Nations and Edward Elgar, Cheltenham, UK.

[13] Dada, James Temitope \& Fanowopo, Oyinkansola. 2020. Economic Growth and Poverty Reduction in Nigeria: The Role of Institutions. Ilorin Journal of Economic Policy Vol.7, No.1: 1-15, 2020.

[14] Dubey, Amaresh \& Tiwari, Shivakar. 2018. Economic Growth and Urban Poverty in India. Environment and Urbanization Asia 9(1) 1-19.

[15] Kanbur, R., \& Squire, L. (1999). The Evolution of Thinking about Poverty: Exploring the Interactions Mimeographed Document. Washington DC: World Development Report Office, Washington DC World Bank.

Ananto Wibowo (ananto.wibowo@bps.go.id)

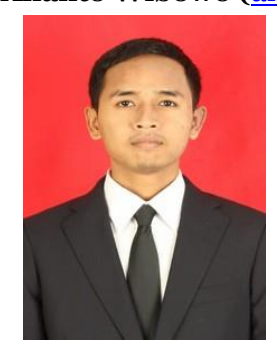
Born on $30^{\text {th }}$ August 1992 in Bandung. He graduated from Institute of Statistics in 2014. He is currently a first statistician at BPS-Statistics Indonesia of Kab. Ciamis West Java. His research interest are Econometrics and Multivariate.

\section{Rismawan Ridha (rismawan.ridha@bps.go.id)}

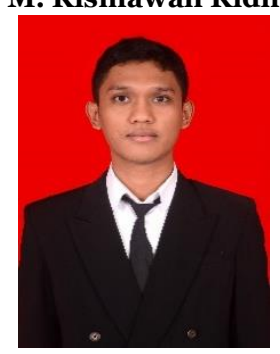

Born on $30^{\text {th }}$ August 1995 in Ambon. He graduated from Institute of Statistics in 2017. He is currently a first statistician at BPS-Statistics Indonesia of Kab. Maluku Tengah. His research interest are Macroeconomics, Econometrics, and forecasting method comparison. 
Ananto Wibowo, M. Rismawan Ridha

d'Cartesian: Jurnal Matematika dan Aplikasi, Vol. 10, No. 1, (Maret 2021): 1-7

\section{Appendix 1. Procedure of Panel Data Regression}

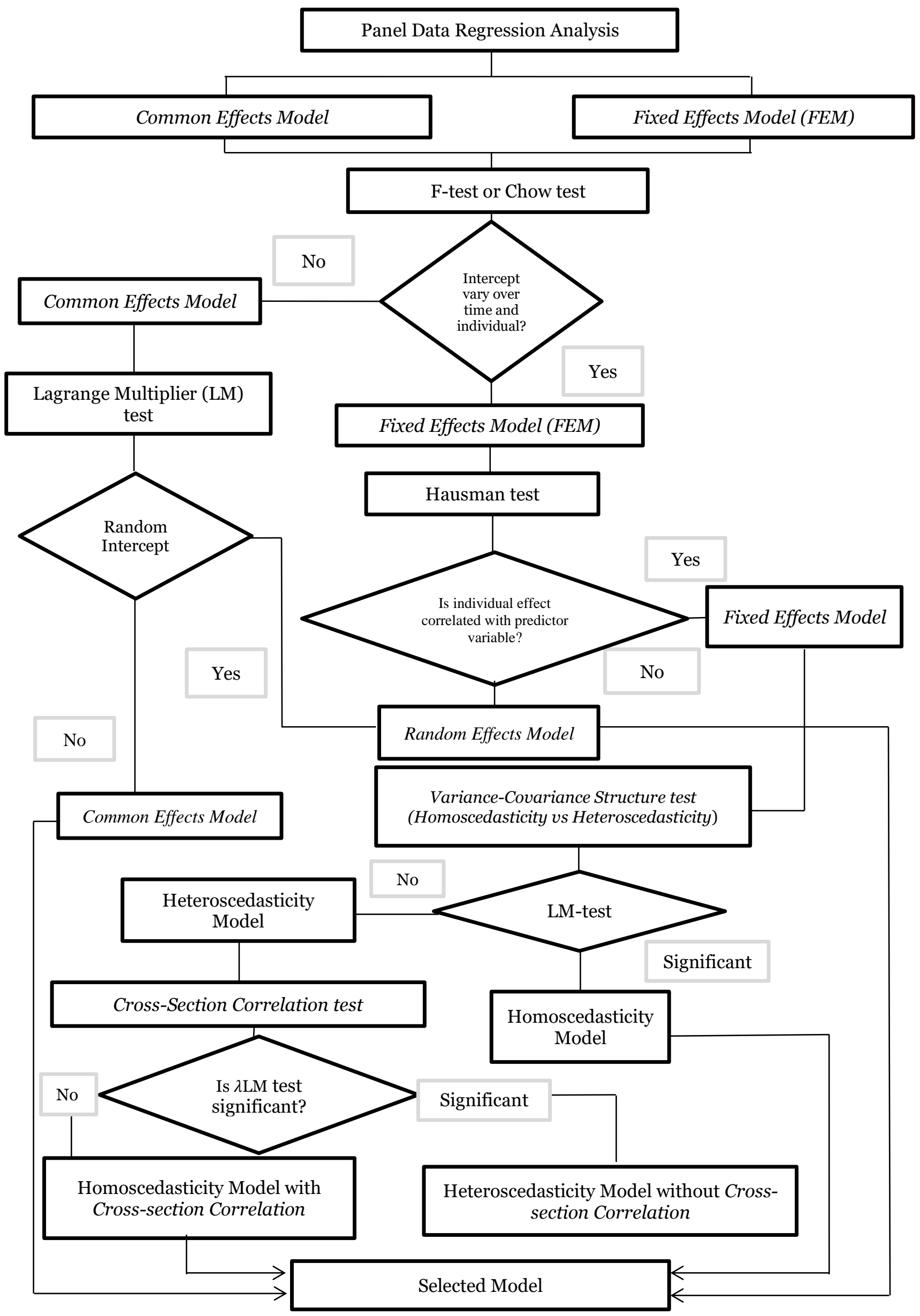


Appendix 2. Percentage of poverty in selected provinces

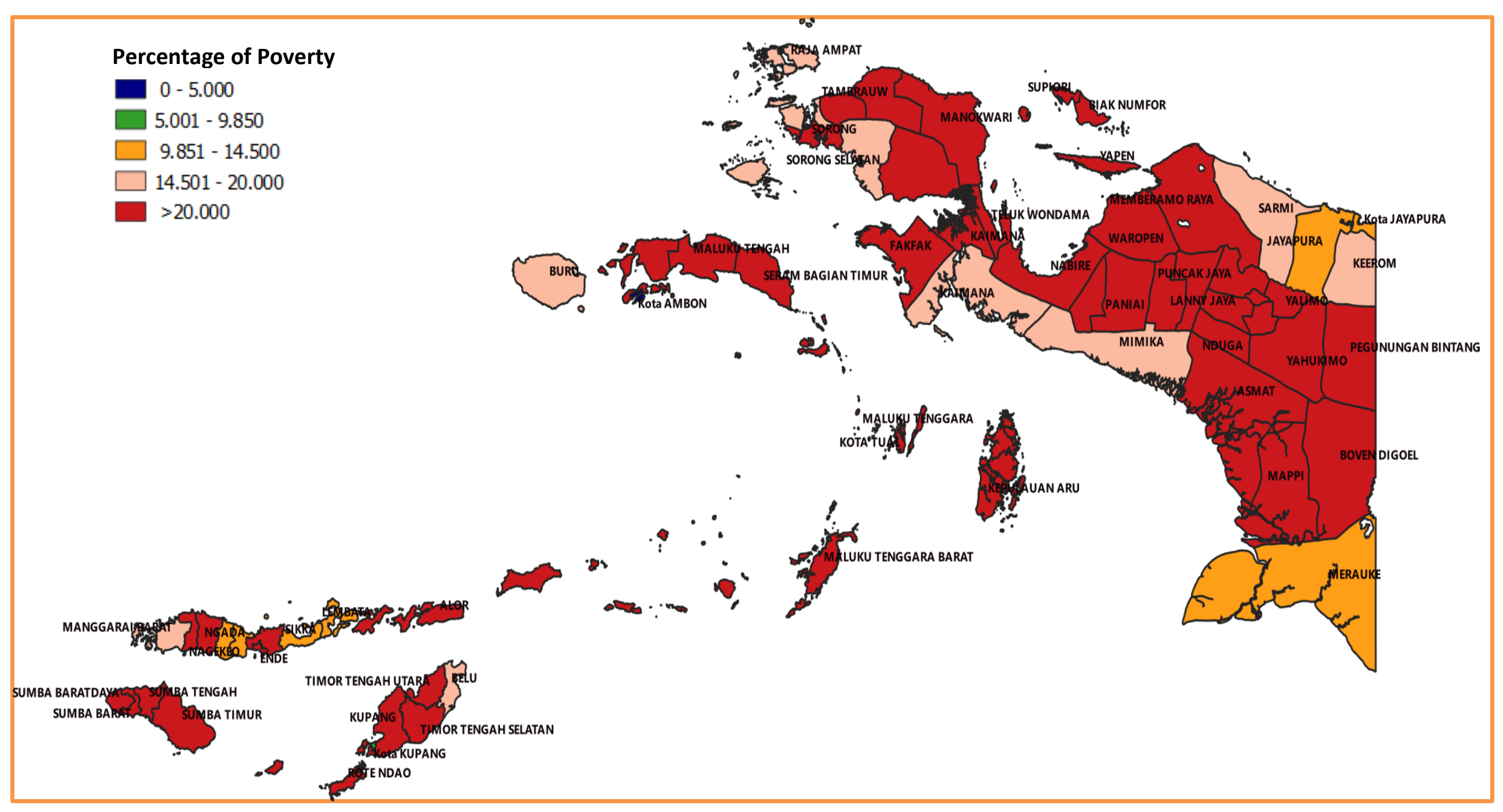

